\title{
Bacterial communities and syntrophic associations involved in anaerobic oxidation of methane process of the Sonora Margin cold seeps, Guaymas Basin
}

\author{
Adrien Vigneron ${ }^{1,2,3}$, Perrine Cruaud ${ }^{1,2,3}$, Patricia Pignet ${ }^{1,2,3}$, Jean-Claude Caprais ${ }^{4}$, Nicolas Gayet ${ }^{4}$, \\ Marie-Anne Cambon-Bonavita ${ }^{1,2,3}$, Anne Godfroy ${ }^{1,2,3}$, Laurent Toffin ${ }^{1,2,3,}$
}

\author{
${ }_{1}^{1}$ Ifremer, Laboratoire de Microbiologie des Environnements Extrêmes, Technopôle Brest Iroise, Plouzané, France \\ 2 Université de Bretagne Occidentale, Technopôle Brest Iroise, Plouzané, France \\ ${ }^{3}$ CNRS, Laboratoire de Microbiologie des Environnements Extrêmes, Technopôle Brest Iroise, Plouzané, France \\ ${ }^{4}$ Ifremer, Laboratoire Etude des Environnements Profonds, Technopôle Brest Iroise, Plouzané, France \\ *: Corresponding author : Laurent Toffin, tel. (+33) 298224396 ; fax (+33) 2982247 ; \\ email address : laurent.toffin@ifremer.fr
}

\begin{abstract}
:
The Sonora Margin cold seeps present on the seafloor a patchiness pattern of white microbial mats surrounded by polychaete and gastropod beds. These surface assemblages are fuelled by abundant organic inputs sedimenting from the water column and upward-flowing seep fluids. Elevated microbial density was observed in the underlying sediments. A previous study on the same samples identified anaerobic oxidation of methane (AOM) as the potential dominant archaeal process in these Sonora Margin sediments, probably catalysed by three clades of archaeal anaerobic methanotrophs (ANME-1, ANME-2 and ANME-3) associated with bacterial syntrophs. In this study, molecular surveys and microscopic observations investigating the diversity of Bacteria involved in AOM process, as well as the environmental parameters affecting the composition and the morphologies of $A O M$ consortia in the Sonora Margin sediments were carried out. Two groups of Bacteria were identified within the AOM consortia, the Desulfosarcina/Desulfococcus SEEP SRB-1a group and a Desulfobulbus-related group. These bacteria showed different niche distributions, association specificities and consortia architectures, depending on sediment surface communities, geochemical parameters and ANMEassociated phylogeny. Therefore, the syntrophic AOM process appears to depend on sulphatereducing bacteria with different ecological niches and/or metabolisms, in a biofilm-like organic matrix.
\end{abstract}

\section{Introduction}

The cold seeps of the Guaymas Basin, located along a transform fault of the Sonora Margin, present different faunal assemblages (Simoneit etal., 1990; Paull etal., 2007) and white microbial mats (Vigneron et al., 2013). The development of these communities at the cold seep water-sediment interface is supported by methane and sulphide-rich up-flowing fluids, and by seep-fuelled active methanogens and anaerobic methanotrophs (Boetius et al., 2000; Jorgensen and Boetius, 2007). Archaeal anaerobic methanotrophs (ANME-1, ANME-2a, ANME-2c and ANME-3), distantly related to the orders Methanosarcinales and Methanomicrobiales (Orphan et al., 2002; Knittel and Boetius, 2009), and probably involved in anaerobic oxidation of methane (AOM), have been found to be dominant in the shallow $(0$ 
to $17 \mathrm{cmbsf}$ ) Sonora Margin cold seep sediments (Vigneron et al., 2013). ANME clades presented different distributions throughout these sediments. In sediments underlying two visible microbial mats, called White Mat 12 (WM12) and White Mat 14 (WM14) (Supplementary Figure 1), ANME-2c were predominant in shallow sulfate-rich sediments while ANME-1 dominated the deepest sulfate-depleted sediment layers and ANME-3 were restricted to a specific horizon below the first $4 \mathrm{~cm}$ of sediments (Figure 3). ANME communities appeared to be favored in sulfate enriched sediments throughout sediment core WM12. Elsewhere, sulfate and methane porewater concentration profiles in sediments underlying macrofauna at the edge of WM14 (called EWM14), were similar to those found in sediments underlying microbial mats. However, in EWM14 sediment core, ANME-2c were restricted to the first sediment layers, while increasing population of ANME-1 appeared to be the sole ANME community in the deepest sediment layers (Figure 3). These ANME lineages are differently associated with syntrophic bacteria, depending on their phylogenetic affiliation and the environmental conditions. In the Sonora Margin sediments, ANME-2a and $-2 \mathrm{c}$ were always observed forming aggregates with bacteria, whereas ANME-1 formed tight associations with bacteria exclusively in sulfate-rich sediments of WM12, and ANME-3 were observed without bacterial partners. Previous studies indicated that such syntrophic relationship between ANME and bacterial partners, mainly affiliated with sulfate-reducing Bacteria (SRB), linked AOM and seawater sulfate reduction in archaeal/bacterial consortia (Orphan et al., 2002; Knittel et al., 2005; Niemann et al., 2006; Pernthaler et al., 2008; Knittel and Boetius, 2009; Schreiber et al., 2010; Schubert et al., 2011). The sulfate-reducing Bacteria, affiliated to the Deltaproteobacteria (Knittel et al., 2003), form a large and diverse physiological group capable of degrading a wide range of organic and hydrocarbon-derived substrates (Dhillon et al., 2003; Kniemeyer et al., 2007), resulting in elevated sulfate reduction rates in cold seep sediments (Bowles et al., 2011). To date, only four phylogenetic clusters were observed in AOM consortia from cold seeps : the two Desulfobulbus-related organism groups (Losekann et al., 2007; Pernthaler et al., 2008), the SEEP SRB1a subgroup belonging to the Desulfosarcina/Desulfococcus group (DSS) (Boetius et al., 2000; Knittel et 
al., 2003; Schreiber et al., 2010) and recently, the previously described group SEEP SRB-2 (Knittel et al., 2003; Kleindienst et al., 2012). Additionally, another deltaproteobacterial group, the Hotseep-1 cluster, was observed in ANME-1 consortia in the hydrothermal sediments of the Guaymas Basin (Holler et al., 2011). However, other unidentified Bacteria have been observed using direct cell capture experimentation (Pernthaler et al., 2008), and AOM has been demonstrated to be coupled with other metabolisms than sulfate reduction, such as iron, manganese or nitrate reduction (Raghoebarsing et al., 2006; Beal et al., 2009). Although these findings have led to the description of the AOM-driving and denitrifying bacteria Candidatus Methylomirabilis oxyfera (Ettwig et al., 2010), these results demonstrated that the diversity of AOM bacterial partners still needs to be completed. Furthermore, the ecophysiology of AOM-involved Bacteria and the exact mechanisms of this syntrophic association remain unclear. For example the vertical distribution and the metabolic specificities of each bacterial partner in the sediments are poorly explored. In this study, we focused on unexplored bacterial communities of the Sonora Margin cold seep sediments and more particularly on Bacteria involved in AOM. The identity and distribution of active bacterial communities involved in AOM were studied using complementary phylogenetic, microscopic and quantitative analyses in conjunction with a previous molecular survey on archaeal communities and geochemical analyses (Vigneron et al., 2013).

\section{$\underline{\text { Results }}$}

\section{Phylogenic diversity of metabolically active Bacteria}

A total of 658 RNA-derived bacterial sequences were analyzed from the sediments underlying two white microbial mats (WM12, a thick mat harboring elevated sulfate concentrations throughout the sampled sediments and WM14, an extended mat surrounding a visible fluid output), and the edge of WM14 (EWM14) colonized by macrofauna. Bacterial diversity was high in the 16S rRNA clone libraries (Simpson indexes:1-HSimpson $=0.9 \pm 0.05$ ), with more than 27 phylogenetic lineages, mainly distributed among the Epsilon, Delta and 
103 Gammaproteobacterial groups (Figure 1 and Supplementary Material Figure 2). The number 104 of sequences related to the Epsilonproteobacteria, and particularly affiliated to the 105 Sulfurovum genus encompassing sulfur- and thiosulfate-oxidizers bacterium (Inagaki et al., 106 2004), decreased with depth. The Deltaproteobacteria represented about a third of analyzed 107 sequences in WM12, WM14 and EWM14 sediment cores. The Deltaproteobacteria 108 sequences were composed of diverse phylogenetic lineages (Figure 2), including the known AOM-associated sulfate-reducing bacterial groups such as the Desulfosarcina/Desulfococcus group (SEEP SRB-1a-f) (Schreiber et al., 2010) and SEEP SRB groups (SRB-2, -3,-4) (Knittel et al., 2003). SEEP SRB-1a were detected throughout the WM12 sediment core, in the middle (4-6 cmbsf) and bottom sediment layers of WM14 and only in the EWM14 surface sediment layer. In contrast, SEEP SRB1b were only detected in the deepest sediment layers of EWM14. The syntrophic AOM partners within the family Desulfobulbaceae, previously described from mud volcano sediments (Losekann et al., 2007), were detected throughout WM sediments and in higher proportion in core WM12. In contrast, in EWM14, Desulfobulbus-related sequences were only detected in the surface and middle sediment layers. SEEP SRB-2 sequences were detected in the deepest layers of WM12 and in higher proportion in EWM14 intermediate and deeper sediment layers. Sequences related to Gammaproteobacteria, previously detected in hydrocarbon rich environments, were also found in high proportion in WM14 sediments and from 0 to $6 \mathrm{cmbsf}$ in EWM14. Sequences related to the Candidatus Maribeggiatoa genus were found in the first centimeters of the WMs (WM14 and WM12) sediments, as well as in dominant proportion in the microbial mats themselves. Additionally, sequences related to uncultured bacterial candidate division JS1 were only detected in the deepest sediment layers of EWM14, that was not covered by microbial mats. Finally, sequences affiliated to several groups of

127 candidate divisions, Bacteroidetes, Spirochaetes, Actinobacterium, Acidobacterium,

128 Chloroflexi and Verrucomicrobia were also detected in all samples in lower proportions 129 (Figure 1 and Supplementary Figure 2). 
DSS, DBB, SEEP-SRB2 and JS1 abundances were estimated by real-time PCR every two centimeters from the water-sediment interface to $15 \mathrm{cmbsf}$ (core length). These quantifications, targeting previously observed or suspected AOM-involved Bacteria (Losekann et al., 2007; Cambon-Bonavita et al., 2009; Harrison et al., 2009; Knittel and Boetius, 2009; Schreiber et al., 2010; Kleindienst et al., 2012), highlighted significant differences between microbial lineage distributions within each habitat. (One-way ANOVA; for WM12, $P<0.01$; WM14, $P<0.01$; EWM14, $P<0.01$ ) (Figure 3). Overall, DSS members were the dominant SRB, as previously reported in other cold seep environments (Kniemeyer et al., 2007; Schreiber et al., 2010). SRB-related 16S rDNA copies were more abundant in WM12 sediments $\left(4.52 \times 10^{9} 16 \mathrm{~S}\right.$ rDNA copies $\left.\mathrm{g}^{-1}\right)$ where sulfate concentrations were high (22 to $13 \mathrm{mM}$ ). Significant differences in DBB and DSS depth distributions were also detected between the habitats (One-way ANOVA; for DSS, $P<0.01$; DBB, $P<0.01$ ). The number of DBB-related 16S rDNA copies increased with depth in WM12 and WM14 sediment cores, reaching a maximum of $2 \times 10^{9} 16 \mathrm{~S}$ rDNA copies $\mathrm{g}^{-1}$ of sediment around 6 to $10 \mathrm{cmbsf}$ in WM12 and $5 \times 10^{8}$ copies $\mathrm{g}^{-1}$ in the $4-6$ cmbsf WM14, then decreased deeper in the sediment. DBB $16 \mathrm{~S}$ rDNA copy number was high $\left(7.8 \times 10^{8}\right.$ copies $\left.^{-1}\right)$ in the first EWM14 sediment layers and then decreased with depth $\left(1.2 \times 10^{7}\right.$ copies $\mathrm{g}^{-1}$ in the bottom of the core) (Figure 3). DSS 16S rDNA copy number in WMs increased with depth until $6 \mathrm{cmbsf}$, reaching $2.6 \times 10^{9}$ and $6 \times 10^{8}$ copies $\mathrm{g}^{-1}$ in WM12 and WM14 respectively, then were fairly constant in the underlying sediment layers. However, in EWM14 sediments, DSS 165 rDNA copy numbers were high $\left(5.8 \times 10^{8}\right.$ copies $\left.\mathrm{g}^{-1}\right)$ in the surface sediment layers $(0-4 \mathrm{cmbsf})$ then fell to $2 \times 10^{8}$ copies $\mathrm{g}^{-1}$ after $4 \mathrm{cmbsf}$ and then increased slightly with depth $\left(4 \times 10^{8}\right.$ copies at the bottom of the core). In contrast to DSS and DBB, SEEP SRB-2 16S rDNA copy numbers were low in all samples (maximum of $3 \times 10^{8}$ copies $\mathrm{g}^{-1}$ in the bottom of WM12) (Figure 3). SEEP SRB-2 16S rDNA concentrations increased slowly with depth in WMs, reaching $2 \times 10^{8}$ copies $\mathrm{g}^{-1}$ in WM14 and fluctuated around $5 \times 10^{7}$ copies $\mathrm{g}^{-1}$ throughout EWM14. However no 
significant difference of SEEP SRB-2 distributions was detected between habitats (One-way ANOVA, $P=0.088$ ). Quantification of candidate division JS1 $16 \mathrm{~S}$ rRNA gene copies indicated another population dynamic. JS1 $16 \mathrm{~S}$ rDNA copies in the sediment underlying WMs were low but increased with depth until reaching $6.9 \times 10^{8}$ copies $\mathrm{g}^{-1}$ for WM12 and $1.2 \times 10^{8}$ copies $\mathrm{g}^{-1}$ for WM14. In contrast, in EWM14 sediments, JS1 $16 \mathrm{~S}$ rDNA copy numbers increased rapidly with depth, from $3.3 \times 10^{7}$ copies $\mathrm{g}^{-1}$ in the surface sediment layer to $9 \times 10^{8}$ copies $\mathrm{g}^{-1}$ at $15 \mathrm{cmbsf}$ (Figure 3 ) and were higher than potential sulfate-reducers related copy numbers.

\section{FISH visualization of bacterial partners in AOM consortia}

FISH observations revealed a high diversity of ANME-2/Bacteria consortia in size, shape and organization (Figure 4B). In order to identify bacterial partners involved in the AOM process in Sonora Margin sediments and to observe the distribution of presumed SRB cells inside the aggregates according to the ANME phylogenetic affiliation, FISH experiments were carried out using specific probes targeting sulfate-reducing bacteria (DSS685, DBB660, SEEP2-658, Supplementary Table 2). SEEP SRB-2 Bacteria, previously reported as syntrophic AOM involved bacteria (Kleindienst et al., 2012), were observed as single tetrads or in monospecific clusters, but did not show direct physical association with ANME cells (Figure 4A). Nevertheless, SEEP SRB-2 monospecific heaps were occasionally observed in proximity with ANME-1 clusters, probably due to the experimental procedure. SEEP SRB-4 cells were observed as free-living bacteria. ANME-2c Archaea were associated with both DSS-hybridized and DBB-hybridized cells and no clear relationship between SRB partner affiliation and morphological appearances of ANME-2c aggregates was observed (Figure 4B). In contrast, ANME-2a formed exclusively intermingled aggregates with DSS-hybridized bacteria ( $n=124)$ (Figure 4C). Tight aggregates of ANME-1 were also observed exclusively associated with DSS-hybridized bacterial cells in WM12 deep sediment layers ( $n=74)$ (Figure 4D). Clusters of monospecific DSS-hybridized cells (Figure 4E) were observed in EWM14 deep sediment layers when DBB-hybridized cells were only found associated with ANME-2c. 
184 Since only one SRB group per aggregate was detected, DSS and DBB appeared to be

185

186

187

188

189

190

191

192

193

194

195

196

197

198

199

200

201

202

203

204

205

206

207

208

209

exclusive in a given aggregate. Additionally, no other Eubacteria-labeled or unlabeled but DAPI-stained cells were detected in physical proximity of ANME consortia. Gammaproteobacteria were observed as large single cells clustered in heaps (Figure 4F) without relationship with ANME.

\section{SEM observations, microanalysis}

In order to investigate the physical interaction between ANME and SRB during AOM association, AOM consortia previously localized by FISH (using ANME2c and bacterial probes, Supplementary Table 2) were observed using SEM (Figure 5). Sediments of WM12 harboring higher numbers of ANME-2 and sulfate reducer aggregates were observed. A high amount of sedimented broken diatoms and aggregate-like structures were detected. ANME2c/Bacterial aggregates appeared to be included in a complex and compact matrix, no individual cells or extracellular structures were detected. Microanalysis of these aggregatelike structures revealed a high proportion of organic compounds ( $55 \% \mathrm{C}, 30 \% \mathrm{O}, 0.39 \% \mathrm{~K}$ ).

\section{Discussion}

\section{Overall bacterial diversity at Sonora Margin sediments}

Using quantitative PCR analysis, Bacteria have been shown to dominate microbial communities in WMs sediments (Vigneron et al., 2013). 16S rRNA gene libraries also demonstrated a higher diversity among Bacteria in the sediment, as previously observed in similar cold seep ecosystems (Lloyd et al., 2010; Orcutt et al., 2010), probably corresponding to the wide range of metabolic functions assumed by Bacteria in ecosystems (Pace, 1997). Indeed, bacterial populations were diverse in the Sonora Margin sediments, with sequences affiliated to Deltaproteobacteria, likely involved in sulfate reduction coupled to the degradation of hydrocarbons or methane in cold seep ecosystems (Dhillon et al., 2003; Knittel et al., 2003; Pereyra et al., 2010) ; Epsilonproteobacteria (Sulfurovum) and Gammaproteobacteria such as Candidatus Maribeggiatoa, potentially involved in sulfate 
oxidation (Crepeau et al., 2011; Grünke et al., 2011; McKay et al., 2012) and other uncultured lineages, previously detected in oil impacted sediments (Head and Swannell, 1999; Orcutt et al., 2010; Pachiadaki et al., 2010; Pachiadaki et al., 2011). Additionally, Spirochaetes, Firmicutes, Acidobacteria, Actinobacteria and diverse candidate divisions with undetermined metabolic roles in seep environments or potentially involved in organic matter degradation (Rappé and Giovannoni, 2003; Stevens et al., 2005; Pachiadaki et al., 2011) were detected.

\section{Bacterial communities involved in syntrophic AOM}

The diversity of bacteria involved in syntrophic AOM with ANME appeared to represent only a third of the total community. Indeed, uncultured lineages of Gammaproteobacteria, detected as predominant in gene libraries, were observed as monospecific clusters without any relationship to ANME, suggesting that they were likely not related to the AOM process. The distribution of bacterial lineages, previously suspected to be involved in AOM, was observed throughout the sediment cores in a centimeter scale. Thus, the candidate division JS1, previously detected in deep marine sediments, tidal flat sediments and hydrothermal vents (Webster et al., 2004; Webster et al., 2007; Biddle et al., 2012), and proposed as a possible partner in AOM (Cambon-Bonavita et al., 2009; Harrison et al., 2009; Roalkvam et al., 2011) or in hydrocarbon-degrading and sulfate-reducing consortia (Phelps et al., 1998), was detected in the EWM14 deepest sediment horizons. Specific quantifications of JS1 $16 \mathrm{~S}$ rDNA highlighted increasing 16S rDNA copy numbers with depth, confirming their strictly anoxic ecological niche (Webster et al., 2004). The distribution of candidate division JS1 appeared to mirror the ANME-1 distribution, particularly in EWM14 sediments $(r=0.98, P$ <0.0001) (Figure 3). However, FISH observations could not validate any bacterial relationship with ANME-1 in EWM14 sediments. These similar distributions of candidate division JS1 and ANME-1 could be due to similar environmental needs/restrictions (methanerich and reduced environments) rather than to a strict relationship between these microorganisms. The SRB Deltaproteobacteria group of SEEP SRB-2, recently observed as 
an AOM partner in the Black Sea microbial mats and in the Gulf of Mexico hydrocarbon seeps (Kleindienst et al., 2012) was detected as metabolically active in our samples, and quantified in low abundance throughout sediment cores, without vertical zonation, as previously observed by FISH in the Tommeliten and Gulf of Mexico seeps and in the Guaymas hydrothermal sediments (Kleindienst et al., 2012). However, our FISH observations could not confirm the physical association with ANMEs. Indeed, SEEP SRB-2 were only observed as single tetrads or monospecific clusters, suggesting that, in the Sonora Margin sediments, SEEP SRB-2 could assume another metabolism, as previously proposed (Kleindienst et al., 2012). Likewise, by using previously designed SRB group specific probes (Knittel et al., 2003), the Deltaproteobacteria SEEP SRB-4 group was observed as free-living single cells, as previously reported (Orcutt et al., 2010). This would suggest that SEEP SRB4 groups are more likely involved in hydrocarbon degradation than in AOM process, as previously suggested (Kleindienst et al., 2012). Presence and metabolic activity of such AOM-independent sulfate-reducers could thereby explain the higher sulfate reduction rates compared to the AOM rates, constantly measured in hydrocarbon-rich cold seeps (Bowles et al., 2011). In contrast, our FISH observations showed that both DSS and DBB relatives were strongly associated in consortia with ANMEs, confirming previous studies (Losekann et al., 2007; Pernthaler et al., 2008). While the DSS/ANME-2 associations are ubiquitously detected in cold seep sediments (Knittel and Boetius 2009), the Sonora margin is only the second AOM environment after the Eel River seeps to harbor DBB/ANME-2 consortia (Pernthaler et al. 2008). However, physical associations of other Bacteria than Deltaproteobacteria within AOM consortia, previously observed by Pernthaler et al., 2008, could not be demonstrated in our samples. In sediments underlying WM14, the proportion of AOM-involved sulfate reducers relative to the total bacterial community, previously estimated by Q-PCR (Vigneron et al., 2013), increased from $2 \%$ at the surface layers to $30 \%$ at the core bottom. These results are consistent with previous estimates of sulfate-reducer abundance in marine sediments and SMTZ, which ranged from $2 \%$ to $35 \%$ (Leloup et al., 2007; Leloup et al., 2009). Moreover, high sulfate concentrations throughout WM12 
265

266

267

268

269

270

271

272

273

274

275

276

277

278

279

280

281

282

283

284

285

286

287

288

289

290

291

sediments seemed to enhance the relative SRB populations with proportions of up to $70 \%$ of the total bacterial community in the core bottom, resulting in an increase in associated ANME abundance. DSS and DBB abundances were comparable in sulfate-riche shallow sediments (0-6 cmbsf) (Figure 3), as previously observed by FISH in Eel River cold seeps (Pernthaler et al., 2008). However, quantification of 16 S rDNA gene copy numbers, targeting the DSS and DBB groups, also highlighted significant differences in depth distribution below $6 \mathrm{cmbsf}$ (Figure 3), as previously presumed in a similar environment (Lloyd et al., 2010). This difference in depth distribution might suggest that SRB involved in AOM could have different ecological niches and/or metabolisms despite the apparent same environmental function, as previously suggested (Pernthaler et al., 2008).

DBB Bacteria, strictly observed in syntrophic relationship with ANME-2c, were restricted to the sulfate-rich surface sediment layers, except in the microbial mat-sediment interface layer, as previously observed in other underlying mat sediments of cold seep ecosystems (Losekann et al., 2007; Pernthaler et al., 2008; Lloyd et al., 2010). Indeed, in EWM14 (without surficial microbial mat), DBB colonized the upper sediment layers, water-sediment interface included, and a significant correlation was observed between DBB distribution and sulfate pore-water concentrations $(r=0.964, P=0.0028)$. This correlation was also observed in WM14 sediments when omitting the surface layer $(r=0.886, P=0.03)$. This result, confirming the sulfate-dependant metabolism of DBB bacteria, would also suggest a probable interference between DBB and the microbial mat. Regarding these results, we hypothesize that DBB bacteria could require an organic carbon source, which could also be coveted by Maribeggiatoa mats. This carbon source, probably derived from surface inputs, would limit the DBB abundance in the deepest WM12 sediment horizons despite the high sulfate concentrations. Thus, DBB bacteria could support a heterotrophic carbon metabolism, as previously observed in other Desulfobulbus family (Sorokin et al., 2012), and participate in the AOM process by reducing the seawater sulfate. Alternatively, the giant filamentous Maribeggiatoa from the surface mats, by their movements or activities, could alter the 
292

293

294

295

296

297

298

299

300

301

302

303

304

305

306

307

308

309

310

311

312

313

314

315

316

317

318

shallow sediment layers and thereby modify the DBB vertical distribution (Salman et al., 2013). The DBB requirements could partially explain the ANME-2c repartition observed in the Sonora Margin sediments, in particular in EWM14 sediments, where ANME-2c mirror the DBB distributions $(r=0.967, P=0.0004)$ (Figure 3). However ANME-2c have also been observed in consortia with DSS bacteria.

The DSS group presented a higher diversity in the gene libraries and at least three of the six previously described SEEP SRB-1 groups (Schreiber et al., 2010) were detected. In EWM14 deep sediments, where no DSS/ANME aggregate was observed, DSS formed monospecific clusters, as previously observed (Omoregie et al., 2008), and gene libraries indicated metabolically active members of the SEEP SRB-1b group, previously suggested as hydrocarbon degraders (Kniemeyer et al., 2007; Schreiber et al., 2010). The DSS 16S rDNA quantifications included the total SEEP SRB-1 (Figure 2), thus the elevated DSS 16S rDNA concentrations in the deepest EWM14 sediment layers could correspond to the SEEP SRB$1 \mathrm{~b}$, independent of ANME, as observed by FISH. In contrast, in WMs, a majority of sequences was affiliated to SEEP SRB1a, known to be involved in AOM (Schreiber et al., 2010), and FISH observations highlighted DSS related bacteria in consortia with both ANME2a,-2c and ANME-1. If sulfate-rich inputs explained a higher DSS abundance throughout WM12 sediments, metabolically active DSS were also detected and quantified in significant proportion $(21 \%)$ in the deep sulfate-depleted sediments of WM14, which was previously observed in other marine sediments (Leloup et al., 2007; Leloup et al., 2009; Lloyd et al., 2010). Even if we could not exclude that DSS bacteria could require lower sulfate concentrations, previous authors suggested that DSS bacteria might switch to a fermentative process or could benefit from a cryptic sulfate formation (Leloup et al., 2007; Lloyd et al., 2010). Indeed, in marine sediments, sulfide could be re-oxidized to sulfate by abiotic reactions with sea water $\mathrm{Fe}^{3+}$ (Yao and Millero, 1996). This sulfate formation would be masked by the DSS sulfate reduction activity at similar rates. Alternatively, DSS, observed within ANME-2c aggregates, could use by disproportionation the intracellular zero-valent 
sulfur stored in ANME-2c cells, which forms polysulfides with environmental sulfide, as previously demonstrated in ANME-2c/DSS enrichments (Milucka et al., 2012). Such metabolism, observed by Milucka et al. at low sulfate concentrations ( $\sim 3 \mathrm{mM})$, would allow the development of these ANME-2c/DSS consortia in sulfate-depleted sediments and thus explain the predominance of DSS and AOM aggregates throughout the WM14 sediment core. Additionally, in contrast to DBB, DSS could use a carbon source available throughout the sediments such as hydrocarbon-derived compounds, as supported by previous DSS enrichments (Dhillon et al., 2003; Kniemeyer et al., 2007), or more likely be lithoautotrophs and assimilate inorganic carbon as recently observed by NanoSIMS analysis of AOM communities (Kellermann et al., 2012; Milucka et al., 2012). Different sulfate requirements, carbon sources and/or environmental interactions for DBB and DSS would account for a distinct distribution of the sulfate-reducing populations and the bacterial partner involved in ANME-2c AOM consortium. The identity of the ANME-2c SRB partners may be dependent on SRB environmental requirements or fluid flow preferences in the sediment. Furthermore, the bacterial partner phylotype did not seem to affect the aggregate morphology (Figure 4). This apparently unspecific and opportunistic association in AOM consortium for ANME-2c could provide a metabolic benefit for ANME-2c, allowing them to colonize a wide range of environmental niches in seep habitats, as compared to ANME-2a (Knittel and Boetius, 2009). This probably also explains the higher ANME-2c abundance estimated by QPCR in the Sonora Margin sediments (Figure 3). Indeed, ANME-2a were observed in mixed and intermingled aggregates exclusively with DSS members, as previously observed (Knittel et al., 2003; Knittel et al., 2005; Schreiber et al., 2010) (Figure 4). This bacterial partner restriction could limit the distribution and abundance of ANME-2a in the Sonora Margin sediments. Likewise, ANME-1 were observed in tight associations only with DSS, as already reported (Orcutt et al., 2005; Maignien et al., 2012). ANME-1 aggregate formation, that we previously suggested to be dependent on a sulfate-concentration threshold (Vigneron et al., 2013), could also be limited by the specificity of their bacterial association. However, the absence of association between ANME-1 and DBB could also be due to antagonist 
environmental requirements and therefore different distributions of ANME- 1 and DBB. These specificities of partners in AOM consortia as well as the detection of only one SRB group per aggregate could indicate that recognition and control mechanisms exist during the setting up of the relationship between AOM partners. Processes remained unexplained but might potentially involved surface proteins and lipids detection, since different lipid compositions have recently been detected between ANME lineage cell membranes (Rossel et al., 2011). Likewise, the electron, zero-valent sulfur (Milucka et al., 2012), nitrogen (Dekas et al., 2009) and/or potential nutrient transfers between the two microbial partners involved in syntrophic AOM remains enigmatic. Different mechanisms have been proposed such as cell-to-cell contacts (Meyerdierks et al., 2010), use of extracellular proteins such as nanowires or interspecies electron shuttles (Knittel and Boetius, 2009; Stams and Plugge, 2009). SEM visualization of ANME-2c/Bacteria aggregates showed that AOM consortia appeared to be included in a complex organic matrix as previously described (Knittel et al., 2005) (Figure 5), probably produced by the consortia themselves. Indeed, the production of extracellular polymers by SRB was previously observed in marine sediments (Zinkevich et al., 1996). As in microbial multi-species biofilms, this organic matrix could protect the microorganisms from environmental stress (oxygen), thus forming a propitious microniche for ANME and SRB,that favors cell-to-cell communications as well as electron or nutrient exchanges (Rickard et al., 2003). This matrix was observed on both large and small aggregates (Figure 5), suggesting a production in the earlier stage in the setting up of the association. This organic boundary could, by the confinement of the first AOM partners, explain the exclusivity of the partnership observed inside aggregates and conserved along the maturation of the aggregate (Nauhaus et al., 2007). Enclosed ANME and SRB would syntrophically grow together inside the matrix, protected from environmental variations or competitive bacterial populations.

\section{Conclusion}

With its geochemically diverse habitats, the Sonora margin cold seeps are an appropriate area to explore microbiological processes occurring in surface sediments 
percolated by methane and sulfide rich fluids. While ANME populations were shown to dominate archaeal communities, bacteria involved in AOM did not seem to be dominant in Sonora Margin cold seep sediments. A wide diversity of active bacteria was observed. However, only two SRB groups, DSS (probably SEEP SRB1a) and DBB, appear to be exclusively associated with ANME in the Sonora Margin cold seeps. This AOM-involved SRB study highlighted different centimeter scale SRB distributions in cold seep sediments. These SRB appear to exhibit specific habitat preference and spatial configuration with archaeal partners in syntrophic AOM, suggesting that these SRB represent unique ecotypes. Different carbon and sulfate metabolisms (sulfate-reduction, Zero valent sulfur disproportionation) coupled to AOM might occur, depending on SRB phylogeny and probably involving different electron transfer pathways or intermediate and partner recognition mechanisms. Comparative genome analysis of the different ANME partners and NanoSims analysis on enrichments of stable ANME-DBB aggregates might lead to a better understanding of biochemical processes involved in the different AOM consortia.

\section{Experimental Procedures}

Sample description

The sediment push cores were sampled at Sonora margin cold seep "Vasconcelos" site during the "BIG" cruise in June 2010. Three different habitats were sampled in the Sonora Margin cold seeps (Supplementary Figure 1). Sediments of White Mat 12 (WM12) and White MAT 14 (WM14) were covered by white bacterial mats, while the water sediment interface of the edge of White Mat14 (EWM14) were colonized by grey polychaetes and gastropods (Vigneron et al., 2013). An autonomous temperature sensor (T-Rov, NKE Electronics, France) indicated in situ temperatures of $3^{\circ} \mathrm{C}$ from the surface water to $50 \mathrm{cmbsf}$ in each habitat before sampling. Immediately after recovery, sediment cores were transferred into a cold room, then aseptically sub-sampled in $2 \mathrm{~cm}$ thick layers and conditioned for molecular and FISH experiments. The sampling strategy and experimental procedures used in this 
400

401

402

403

404

405

406

407

408

409

410

411

412

413

414

415

416

417

418

419

420

421

422

423

424

425

426

study were detailed in a previous work based on an archaeal survey (Vigneron et al., 2013).

Detailed geochemical measurements and ANME concentrations are provided in Figure 3. Sediment RNA extractions, cDNA clone libraries and sequencing.

16S rRNA amplification was used as a proxy for the detection of active microbial populations (Lloyd et al., 2010). RNA was extracted using the Zhou protocol (Zhou et al., 1996) with modifications (Lazar et al., 2010) and purified using Nucleospin® RNA II kit (Macherey Nagel, Düren, Germany). Absence of residual DNA contamination was verified by PCR. Reverse transcription PCR of $16 \mathrm{~S}$ rRNA were carried out by a two-step protocol with a preliminary reverse transcription step using Quanta qScript ${ }^{\circledR}$ kit (Quanta Bioscience, Gaithersburg, MD, USA). PCR reactions contained $10 \mathrm{ng}$ of reverse transcribed RNA template, 1 X PCR Buffer, $2 \mathrm{nM} \mathrm{MgCl}$, $0.2 \mathrm{mM}$ of each dNTP, $0.4 \mathrm{mM}$ of each primer (E338f 5'- ACT CCT ACG GGA GGC AGC-3' and U1407r 5'-GAC GGG CGG TGW GTR CAA-3') and 0.6 U GoTaq DNA polymerase (Promega BioSciences, San Luis Obispo CA, USA). Amplifications were carried out using the GeneAmp PCR 9700 System (Applied Biosystems, Foster City, CA, USA) as follows: denaturation step at $94^{\circ} \mathrm{C}$ for $1 \mathrm{~min}$, annealing for $1 \mathrm{~min} 30$ $\mathrm{s}$ at $54^{\circ} \mathrm{C}$ and extension step for $2 \mathrm{~min}$ at $72^{\circ} \mathrm{C}$ for 30 cycles. For gene library construction, the 16S rRNA were reverse transcribed, amplified in triplicate and pooled before gel purification. Purified amplification products were cloned into TOPO ${ }^{\circledR}$ XL PCR Cloning Kit, and transformed into Escherichia coli TOP10 cells (Invitrogen, Carlsbad, CA, USA) according to the manufacturer's recommendations. 16S rRNA gene sequences were determined on an ABI3730xl - genetic Analyzer using M13 universal primers (GATC Biotech, Germany). Sequences were analyzed using the NCBI BLASTn search program within GenBank (Altschul et al., 1990). Sequences were aligned with closest representative sequences from GenBank using MAFFT 6.903 (Katoh et al., 2005) and checked manually for chimera. Phylogenetic trees were estimated with maximum likelihood methods, using MPI-parallelized RAxML 7.2.8. (Stamatakis, 2006) on the CIPRES Science Gateway (Miller et al., 2011). GTRCAT approximation of models was used for ML bootstrapping (1000). Simpson indexes 
were calculated using DOTUR as previously detailed (Guri et al., 2012). Sequences from cDNA libraries affiliated to the Deltaproteobacteria were deposited in the EMBL database under accession numbers: HE972157-HE972208 and other Bacteria under HF545525HF545595.

\section{Quantitative real-time PCR}

Real-time PCR amplifications were performed in triplicate using Perfecta $§$ SYBR® Green SuperMix ROX (Quanta Bioscience) according to the manufacturer's recommendations. Amplifications followed a two step PCR (40 cycles) with $15 \mathrm{~s}$ denaturation $\left(95^{\circ} \mathrm{C}\right)$ and $1 \mathrm{~min}$ annealing/elongation step at $60^{\circ} \mathrm{C}$. Primer concentrations were optimized, as recommended by the manufacturer, to minimize the formation of secondary structure and to maximize the efficiency of the reaction. New primer sets, specific for SRB groups and candidate division JS1, were designed using the ARB package (Ludwig et al., 2004) and web-based application Primaclade (Gadberry et al., 2005) and are listed in Supplementary Table 1. Primers were checked for specificity by using Oligocheck software and tested by PCR on various environmental clones from the Sonora Margin sediments. Triplicate standard curves were obtained with ten-fold serial dilutions of plasmids containing environmental 16S rRNA sequences relative to DSS, DBB, SEEP SRB-2 or JS1 and ranged from $10^{4}$ to $10^{8}$ copies/ $\mu \mathrm{L}$ of $16 \mathrm{~S}$ rDNA. The $\mathrm{R}^{2}$ of standard curves obtained by real time PCR were up to 0.997 and efficiency of the reaction up to $98 \%$. The primer set specificity was confirmed by control sequencing of amplification products. Samples were diluted to a concentration for which no inhibitory effect was observed. Correlation factors and statistical tests on the microbial distribution were achieved using Graph Pad Prism Software.

Fluorescence In Situ Hybridizations (FISH)

Immediately after the core recovery, two grams of sediment collected from each layer were fixed in PBS (1X)/formaldehyde ( $3 \%$ final) at $4^{\circ} \mathrm{C}$ for 4 hours then washed twice with PBS(1X) and stored in PBS(2X)/Ethanol (1:1, vol/vol) buffer at $-20^{\circ} \mathrm{C}$. Twenty microlitres of a 
100 fold dilution of the sample were immobilized on $0.22 \mu \mathrm{m}$ GTTP polycarbonate filters

454

455 (Merck Milipore, Darmstadt, Germany) for FISH observations. For filters observed by SEM after FISH, fixed sediments were sonicated (40 fold $1 \mathrm{sec}, 40 \%$ intensity, Vibra Cell, Biolock Scientific, France) before immobilization on fine-tipped pen squared filters. Hybridization was carried out for 3 hours at $46^{\circ} \mathrm{C}$ in formamide buffer with labeled probes (Supplementary Table 2). After 20 min in washing buffer at $48^{\circ} \mathrm{C}$, filters were fixed on slides and covered with an antifade/DAPI solution (SlowFade ${ }^{\circledR}$ Gold, Invitrogen). As cross hybridization between DSS and SEEP SRB-2 probes was recently observed (Kleindienst et al., 2012), detection of AOMinvolved SRB were monitored combining the three SRB probes with $50 \%$ formamide and no co-localized signal was detected. In order to conclude on the aggregate morphologies and partnership specificities, two replicate filters (each harboring over 100 aggregates) were fully explored for each sediment layer previously analyzed by gene libraries. Observations and imaging were performed using an epifluorescence Axio Imager Z2 microscope equipped with the Apotome ${ }^{\circledR}$ system and the COLIBRI ${ }^{\circledR}$ technology (Zeiss, Jena, Germany). ANME/Bacteria aggregate location was noted in order to be observed by SEM.

\section{Scanning Electron Microscopy (SEM)}

Immediately after FISH observations, filters were completely dried at room temperature and then directly metalized with gold and palladium (60/40) using a high resolution Sputter Coater (Quorum Technologies, Guelph, Canada). SEM observations and imaging were performed using a FEI Quanta 200 microscope (FEl, Oregon, USA) and micro analyzes performed with EDX microelectrode (Oxford instruments, Abingdon, UK).

\section{Acknowledgements}

We are indebted to the crews of the research vessel L'Atalante and the submersible Nautile of the cruise "BIG" and the scientific team for their contribution in sampling on board. This 
cruise and work was funded by IFREMER (France) and has benefited from a work permit in

Mexican waters (DAPA/2/281009/3803, October 28th, 2009).

Altschul, S.F., Gish, W., Miller, W., Myers, E.W., and Lipman, D.J. (1990) Basic local alignment search tool. J Mol Biol 215: 403-410.

Beal, E.J., House, C.H., and Orphan, V.J. (2009) Manganese- and iron-dependent marine methane oxidation. Science 325: 184-187.

Biddle, J.F., Cardman, Z., Mendlovitz, H., Albert, D.B., Lloyd, K.G., Boetius, A., and Teske, A. (2012) Anaerobic oxidation of methane at different temperature regimes in Guaymas Basin hydrothermal sediments. Isme Journal 6: 1018-1031.

Boetius, A., Ravenschlag, K., Schubert, C.J., Rickert, D., Widdel, F., Gieseke, A. et al. (2000) A marine microbial consortium apparently mediating anaerobic oxidation of methane. Nature 407: 623-626.

Bowles, M.W., Samarkin, V.A., Bowles, K.M., and Joye, S.B. (2011) Weak coupling between sulfate reduction and the anaerobic oxidation of methane in methane-rich seafloor sediments during ex situ incubation. Geochimica Et Cosmochimica Acta 75: 500-519.

Cambon-Bonavita, M.A., Nadalig, T., Roussel, E., Delage, E., Duperron, S., Caprais, J.C. et al. (2009) Diversity and distribution of methane-oxidizing microbial communities associated with different faunal assemblages in a giant pockmark of the Gabon continental margin. Deep-Sea Research Part IiTopical Studies in Oceanography 56: 2248-2258.

Crepeau, V., Bonavita, M.A.C., Lesongeur, F., Randrianalivelo, H., Sarradin, P.M., Sarrazin, J., and Godfroy, A. (2011) Diversity and function in microbial mats from the Lucky Strike hydrothermal vent field. FEMS Microbiol Ecol 76: 524-540.

Dekas, A.E., Poretsky, R.S., and Orphan, V.J. (2009) Deep-sea archaea fix and share nitrogen in methane-consuming microbial consortia. Science 326: 422-426.

Dhillon, A., Teske, A., Dillon, J., Stahl, D.A., and Sogin, M.L. (2003) Molecular characterization of sulfate-reducing bacteria in the Guaymas Basin. Appl Environ Microbiol 69: 2765-2772.

Ettwig, K.F., Butler, M.K., Le Paslier, D., Pelletier, E., Mangenot, S., Kuypers, M.M.M. et al. (2010) Nitrite-driven anaerobic methane oxidation by oxygenic bacteria. Nature 464: 543-+.

Gadberry, M.D., Malcomber, S.T., Doust, A.N., and Kellogg, E.A. (2005) Primaclade--a flexible tool to find conserved PCR primers across multiple species. Bioinformatics 21: 1263-1264.

Grünke, S., Felden, J., Lichtschlag, A., Girnth, A.C., De Beer, D., WenzhÖFer, F., and Boetius, A. (2011) Niche differentiation among mat-forming, sulfide-oxidizing bacteria at cold seeps of the Nile Deep Sea Fan (Eastern Mediterranean Sea). Geobiology 9: 330-348.

Guri, M., Durand, L., Cueff-Gauchard, V., Zbinden, M., Crassous, P., Shillito, B., and Cambon-Bonavita, M.A. (2012) Acquisition of epibiotic bacteria along the life cycle of the hydrothermal shrimp Rimicaris exoculata. Isme Journal 6: 597-609.

Harrison, B.K., Zhang, H., Berelson, W., and Orphan, V.J. (2009) Variations in archaeal and bacterial diversity associated with the sulfate-methane transition zone in continental margin sediments (Santa Barbara Basin, California). Appl Environ Microbiol 75: 1487-1499.

Head, I.M., and Swannell, R.P.J. (1999) Bioremediation of petroleum hydrocarbon contaminants in marine habitats. Current Opinion in Biotechnology 10: 234-239.

Holler, T., Widdel, F., Knittel, K., Amann, R., Kellermann, M.Y., Hinrichs, K.U. et al. (2011) Thermophilic anaerobic oxidation of methane by marine microbial consortia. ISME J 5: 1946-1956.

Inagaki, F., Tsunogai, U., Suzuki, M., Kosaka, A., Machiyama, H., Takai, K. et al. (2004) Characterization of C1-metabolizing prokaryotic communities in methane seep habitats at the Kuroshima Knoll, southern Ryukyu Arc, by analyzing pmoA, mmoX, mxaF, mcrA, and 165 rRNA genes. Appl Environ Microbiol 70: 7445-7455. 
525 Jorgensen, B.B., and Boetius, A. (2007) Feast and famine--microbial life in the deep-sea bed. Nat Rev 526 Microbiol 5: 770-781.

527 Katoh, K., Kuma, K., Toh, H., and Miyata, T. (2005) MAFFT version 5: improvement in accuracy of multiple sequence alignment. Nucleic Acids Research 33: 511-518.

529 Kellermann, M.Y., Wegener, G., Elvert, M., Yoshinaga, M.Y., Lin, Y.-S., Holler, T. et al. (2012) 530 Autotrophy as a predominant mode of carbon fixation in anaerobic methane-oxidizing microbial communities. Proceedings of the National Academy of Sciences 109: 19321-19326.

Kleindienst, S., Ramette, A., Amann, R., and Knittel, K. (2012) Distribution and in situ abundance of sulfate-reducing bacteria in diverse marine hydrocarbon seep sediments. Environ Microbiol: no-no.

534 Kniemeyer, O., Musat, F., Sievert, S.M., Knittel, K., Wilkes, H., Blumenberg, M. et al. (2007) Anaerobic 535 oxidation of short-chain hydrocarbons by marine sulphate-reducing bacteria. Nature 449: 898-U810.

536 Knittel, K., and Boetius, A. (2009) Anaerobic Oxidation of Methane: Progress with an Unknown 537 Process. Annual Review of Microbiology 63: 311-334.

538 Knittel, K., Losekann, T., Boetius, A., Kort, R., and Amann, R. (2005) Diversity and distribution of 539 methanotrophic archaea at cold seeps. Appl Environ Microbiol 71: 467-479.

540 Knittel, K., Boetius, A., Lemke, A., Eilers, H., Lochte, K., Pfannkuche, O. et al. (2003) Activity, 541 distribution, and diversity of sulfate reducers and other bacteria in sediments above gas hydrate 542 (Cascadia margin, Oregon). Geomicrobiology Journal 20: 269-294.

543 Lazar, C.S., Dinasquet, J., Pignet, P., Prieur, D., and Toffin, L. (2010) Active archaeal communities at 544 cold seep sediments populated by Siboglinidae tubeworms from the Storegga Slide. Microb Ecol 60: 545 516-527.

546 Leloup, J., Loy, A., Knab, N.J., Borowski, C., Wagner, M., and Jorgensen, B.B. (2007) Diversity and 547 abundance of sulfate-reducing microorganisms in the sulfate and methane zones of a marine 548 sediment, Black Sea. Environ Microbiol 9: 131-142.

549 Leloup, J., Fossing, H., Kohls, K., Holmkvist, L., Borowski, C., and Jorgensen, B.B. (2009) Sulfate550 reducing bacteria in marine sediment (Aarhus Bay, Denmark): abundance and diversity related to geochemical zonation. Environmental Microbiology 11: 1278-1291.

Lloyd, K.G., Albert, D.B., Biddle, J.F., Chanton, J.P., Pizarro, O., and Teske, A. (2010) Spatial structure and activity of sedimentary microbial communities underlying a Beggiatoa spp. mat in a Gulf of Mexico hydrocarbon seep. PLoS One 5: e8738.

Losekann, T., Knittel, K., Nadalig, T., Fuchs, B., Niemann, H., Boetius, A., and Amann, R. (2007) Diversity and abundance of aerobic and anaerobic methane oxidizers at the Haakon Mosby Mud Volcano, Barents Sea. Appl Environ Microbiol 73: 3348-3362.

Ludwig, W., Strunk, O., Westram, R., Richter, L., Meier, H., Yadhukumar et al. (2004) ARB: a software environment for sequence data. Nucleic Acids Res 32: 1363-1371.

Maignien, L., Parkes, R.J., Cragg, B., Niemann, H., Knittel, K., Coulon, S. et al. (2012) Anaerobic oxidation of methane in hypersaline cold seep sediments. FEMS Microbiol Ecol: n/a-n/a.

McKay, L.J., MacGregor, B.J., Biddle, J.F., Albert, D.B., Mendlovitz, H.P., Hoer, D.R. et al. (2012) Spatial heterogeneity and underlying geochemistry of phylogenetically diverse orange and white Beggiatoa mats in Guaymas Basin hydrothermal sediments. Deep Sea Research Part I: Oceanographic Research Papers 67: 21-31.

Meyerdierks, A., Kube, M., Kostadinov, I., Teeling, H., Glockner, F.O., Reinhardt, R., and Amann, R. (2010) Metagenome and mRNA expression analyses of anaerobic methanotrophic archaea of the ANME-1 group. Environ Microbiol 12: 422-439.

Miller, M.A., Pfeiffer, W., and Schwartz, T. (2011) The CIPRES science gateway: a community resource for phylogenetic analyses. In Proceedings of the 2011 TeraGrid Conference: Extreme Digital Discovery. Salt Lake City, Utah: ACM, pp. 1-8.

Milucka, J., Ferdelman, T.G., Polerecky, L., Franzke, D., Wegener, G., Schmid, M. et al. (2012) Zerovalent sulphur is a key intermediate in marine methane oxidation. Nature 491: 541-+.

Nauhaus, K., Albrecht, M., Elvert, M., Boetius, A., and Widdel, F. (2007) In vitro cell growth of marine archaeal-bacterial consortia during anaerobic oxidation of methane with sulfate. Environ Microbiol 9: 187-196. 
577 Niemann, H., Losekann, T., de Beer, D., Elvert, M., Nadalig, T., Knittel, K. et al. (2006) Novel microbial 578 communities of the Haakon Mosby mud volcano and their role as a methane sink. Nature 443: 854579858.

580 Omoregie, E.O., Mastalerz, V., de Lange, G., Straub, K.L., Kappler, A., Roy, H. et al. (2008) 581 Biogeochemistry and community composition of iron- and sulfur-precipitating microbial mats at the 582 Chefren mud volcano (Nile Deep Sea Fan, Eastern Mediterranean). Appl Environ Microbiol 74: 31985833215.

584 Orcutt, B., Boetius, A., Elvert, M., Samarkin, V., and Joye, S.B. (2005) Molecular biogeochemistry of 585 sulfate reduction, methanogenesis and the anaerobic oxidation of methane at Gulf of Mexico cold 586 seeps. Geochimica Et Cosmochimica Acta 69: 4267-4281.

587 Orcutt, B.N., Joye, S.B., Kleindienst, S., Knittel, K., Ramette, A., Reitz, A. et al. (2010) Impact of natural 588 oil and higher hydrocarbons on microbial diversity, distribution, and activity in Gulf of Mexico cold589 seep sediments. Deep Sea Research Part II: Topical Studies in Oceanography 57: 2008-2021.

590 Orphan, V.J., House, C.H., Hinrichs, K.U., McKeegan, K.D., and DeLong, E.F. (2002) Multiple archaeal 591 groups mediate methane oxidation in anoxic cold seep sediments. Proceedings of the National 592 Academy of Sciences of the United States of America 99: 7663-7668.

593 Pace, N.R. (1997) A Molecular View of Microbial Diversity and the Biosphere. Science 276: 734-740.

594 Pachiadaki, M.G., Lykousis, V., Stefanou, E.G., and Kormas, K.A. (2010) Prokaryotic community 595 structure and diversity in the sediments of an active submarine mud volcano (Kazan mud volcano, 596 East Mediterranean Sea). FEMS Microbiol Ecol 72: 429-444.

597 Pachiadaki, M.G., Kallionaki, A., Dahlmann, A., De Lange, G.J., and Kormas, K.A. (2011) Diversity and 598 spatial distribution of prokaryotic communities along a sediment vertical profile of a deep-sea mud 599 volcano. Microb Ecol 62: 655-668.

600 Paull, C.K., Ussler, W., Peltzer, E.T., Brewer, P.G., Keaten, R., Mitts, P.J. et al. (2007) Authigenic carbon 601 entombed in methane-soaked sediments from the northeastern transform margin of the Guaymas 602 Basin, Gulf of California. Deep-Sea Research Part li-Topical Studies in Oceanography 54: 1240-1267. Pereyra, L.P., Hiibel, S.R., Riquelme, M.V.P., Reardon, K.F., and Pruden, A. (2010) Detection and Quantification of Functional Genes of Cellulose-Degrading, Fermentative, and Sulfate-Reducing Bacteria and Methanogenic Archaea. Appl Environ Microbiol 76: 2192-2202.

Pernthaler, A., Dekas, A.E., Brown, C.T., Goffredi, S.K., Embaye, T., and Orphan, V.J. (2008) Diverse syntrophic partnerships from deep-sea methane vents revealed by direct cell capture and metagenomics. Proc Natl Acad Sci U S A 105: 7052-7057.

Phelps, C.D., Kerkhof, L.J., and Young, L.Y. (1998) Molecular characterization of a sulfate-reducing consortium which mineralizes benzene. FEMS Microbiol Ecol 27: 269-279.

Raghoebarsing, A.A., Pol, A., van de Pas-Schoonen, K.T., Smolders, A.J.P., Ettwig, K.F., Rijpstra, W.I.C. et al. (2006) A microbial consortium couples anaerobic methane oxidation to denitrification. Nature 440: 918-921.

Rappé, M.S., and Giovannoni, S.J. (2003) THE UNCULTURED MICROBIAL MAJORITY. Annual Review of Microbiology 57: 369-394.

Rickard, A.H., Gilbert, P., High, N.J., Kolenbrander, P.E., and Handley, P.S. (2003) Bacterial coaggregation: an integral process in the development of multi-species biofilms. Trends Microbiol 11: 94-100.

Roalkvam, I., Jorgensen, S.L., Chen, Y.F., Stokke, R., Dahle, H., Hocking, W.P. et al. (2011) New insight into stratification of anaerobic methanotrophs in cold seep sediments. FEMS Microbiol Ecol 78: 233243.

Rossel, P.E., Elvert, M., Ramette, A., Boetius, A., and Hinrichs, K.-U. (2011) Factors controlling the distribution of anaerobic methanotrophic communities in marine environments: Evidence from intact polar membrane lipids. Geochimica Et Cosmochimica Acta 75: 164-184.

Salman, V., Bailey, J.V., and Teske, A. (2013) Phylogenetic and morphologic complexity of giant sulphur bacteria. Antonie Van Leeuwenhoek 104: 169-186. 
627 Schreiber, L., Holler, T., Knittel, K., Meyerdierks, A., and Amann, R. (2010) Identification of the 628 dominant sulfate-reducing bacterial partner of anaerobic methanotrophs of the ANME-2 clade. 629 Environ Microbiol 12: 2327-2340.

630 Schubert, C.J., Vazquez, F., Losekann-Behrens, T., Knittel, K., Tonolla, M., and Boetius, A. (2011) 631 Evidence for anaerobic oxidation of methane in sediments of a freshwater system (Lago di Cadagno).

632 FEMS Microbiol Ecol 76: 26-38.

633 Simoneit, B.R.T., Lonsdale, P.F., Edmond, J.M., and Shanks, W.C. (1990) Deep-Water Hydrocarbon 634 Seeps in Guaymas Basin, Gulf of California. Applied Geochemistry 5: 41-49.

635 Sorokin, D.Y., Tourova, T.P., Panteleeva, A.N., and Muyzer, G. (2012) Desulfonatronobacter 636 acidivorans gen. nov., sp. nov. and Desulfobulbus alkaliphilus sp. nov., haloalkaliphilic heterotrophic 637 sulfate-reducing bacteria from soda lakes. International Journal of Systematic and Evolutionary 638 Microbiology 62: 2107-2113.

639 Stamatakis, A. (2006) RAxML-VI-HPC: maximum likelihood-based phylogenetic analyses with 640 thousands of taxa and mixed models. Bioinformatics 22: 2688-2690.

641 Stams, A.J.M., and Plugge, C.M. (2009) Electron transfer in syntrophic communities of anaerobic 642 bacteria and archaea. Nature Reviews Microbiology 7: 568-577.

643 Stevens, H., Stübner, M., Simon, M., and Brinkhoff, T. (2005) Phylogeny of Proteobacteria and 644 Bacteroidetes from oxic habitats of a tidal flat ecosystem. FEMS Microbiol Ecol 54: 351-365.

645 Vigneron, A., Cruaud, P., Pignet, P., Caprais, J.-C., Cambon-Bonavita, M.-A., Godfroy, A., and Toffin, L. 646 (2013) Archaeal and anaerobic methane oxidizer communities in the Sonora Margin cold seeps, 647 Guaymas Basin (Gulf of California). ISME J.

648 Webster, G., Parkes, R.J., Fry, J.C., and Weightman, A.J. (2004) Widespread occurrence of a novel 649 division of bacteria identified by $16 \mathrm{~S}$ rRNA gene sequences originally found in deep marine

650

651

652

653

654

655

656

657

658

659

660

661

662

Figure 2: Maximum Likelihood phylogenetic tree of the bacterial Deltaproteobacteria 16S

Sediments. Appl Environ Microbiol 70: 5708-5713.

Webster, G., Yarram, L., Freese, E., Koster, J., Sass, H., Parkes, R.J., and Weightman, A.J. (2007) Distribution of candidate division JS1 and other Bacteria in tidal sediments of the German Wadden Sea using targeted 16S rRNA gene PCR-DGGE. FEMS Microbiol Ecol 62: 78-89.

Yao, W., and Millero, F.J. (1996) Oxidation of hydrogen sulfide by hydrous Fe(III) oxides in seawater. Marine Chemistry 52: 1-16.

Zhou, J., Bruns, M.A., and Tiedje, J.M. (1996) DNA recovery from soils of diverse composition. Appl Environ Microbiol 62: 316-322.

Zinkevich, V., Bogdarina, I., Kang, H., Hill, M.A.W., Tapper, R., and Beech, I.B. (1996) Characterisation of exopolymers produced by different isolates of marine sulphate-reducing bacteria. International Biodeterioration \& Biodegradation 37: 163-172.

\section{$\underline{\text { Table and Figure legends }}$}

Figure 1: Phylogenetic affiliations of bacterial 16S cDNA sequences for cold seep sediments of the Sonora Margin from Top (0 to $4 \mathrm{cmbsf}$ ), Middle (4 to $6 \mathrm{cmbsf}$ ) and Bottom (8 to 12 cmbsf). Shades of red, green, and blue denote putative Proteobacteria (Epsilon-, Delta- and Gamma- respectively). A,B and C correspond to the three selected habitats : white MAT12, White MAT14 and Edge of White MAT14.

cDNA sequences in sediments of the Sonora Margin cold seeps performed using RAxML 
7.2.8 and GTRCAT model approximation with 1000 replicates. Only bootstrap values up to $70 \%$ are shown. Sequences amplified from sections 0 to $4 \mathrm{cmbsf}$ are labeled "Top", sequences from 4 to $6 \mathrm{cmbsf}$ are "Middle" and sequences from $8 \mathrm{cmbsf}$ to end are tagged "Bottom". Only one representative sequence (>97\% identical) is shown. Number in brackets shown the number of clones analyzed from RNA clone libraries. Dotted lines and dashes indicate sequences matching with corresponding Q-PCR primers and FISH probes, respectively. White MAT12, WM12; White MAT14, WM14; EWM14, Edge of White MAT14.

Figure 3: I Geochemical description of the three selected habitats A) White MAT12 (WM12), B) White MAT14 (WM14) and C) Edge White MAT14 (EWM14). Dissolved methane (cross), sulfate (open square) and sulfide (black square) concentrations in porewaters. II DNA copy numbers of the 16S rDNA gene per gram of sediment for ANME groups previously observed on the same samples in the Sonora Margin sediments (Vigneron et al. 2013). III DNA copy numbers of the 16S rDNA gene per gram of sediment for bacterial groups Desulfosarcina/Desulfoccocus, Desulfobulbus, SEEP SRB2 and candidate division JS1 in function of depth (0 to $15 \mathrm{cmbsf}$ ) in cold seep sediments of the Sonora Margin. Differences between DSS and DBB abundances were tested with t-test and labeled with ${ }^{* * *} P<0.0001$, ${ }^{* *} P<0.001$ and ${ }^{*} P<0.01$. IV Proportion of sulfate reducing bacteria to total bacterial community previously estimated by Q-PCR

Figure 4: Individual cells and cell aggregates of ANMEs and bacterial partners visualized with fluorescent-labeled oligonucleotide probes. Each presented aggregate was taken from different pictures. $A_{1}$ and $A_{2}$ ) Monophyletic aggregate and single tetrad of SEEP SRB2 labeled with SEEP2-658 (Orange). B) Aggregates of ANME-2c (ANME2c-622 Yellow) and DSS cells (B1 and B3) or DBB cells (B2). C) Mixed aggregate of ANME-2a (ANME2a647IDSS (DSS-658 green). D) Tight aggregates of ANME-1 (ANME-1-350 -Yellow) and DSS (DSS-658 Green). E) Homogeneous aggregate of DSS cells labeled with DSS-658 probe (Green). F) Monospecific clusters of Gammaproteobacteria cells labeled with GAM42a probe (Blue). Scale is $10 \mu \mathrm{m}$. Pictures A B and F were from WM14 middle sediment layer, picture C 
697 from WM12 middle sediment layer, picture D from the bottom sediment layer of WM12 and

698 picture $\mathrm{E}$ from the deepest sediment layer of EWM14.

699 Figure 5: FISH $\left(A_{1}\right.$ and $\left.B_{1}\right)$ and $\operatorname{SEM}\left(A_{2}\right.$ and $\left.B_{2}\right)$ observations of ANME-2c/Bacteria 700 aggregates on WM12 bottom sediment layers.

\section{Supplementary Material}

702

703

704

705

706

707

708

709

710

711

712

713

714

715

716

717

718

Supplementary Figure 1: Schematic view of sampling sites around markers BIG18 (N $27^{\circ} 35.5781$; W $\left.111^{\circ} 28.9848\right)$ with Nautile dives areas (PL), relative position of push cores (CT, Diameter $5 \mathrm{~cm}$, length $30 \mathrm{~cm})$ and their geochemical measurements $\left(\mathrm{CH}_{4}\right.$ for methane concentrations, $\mathrm{SO}_{4}$ for sulfate and $\mathrm{H}_{2} \mathrm{~S}$ for sulfide) and microbiological analysis (M). Scale is 1 meter. Modified from Vigneron et al., 2013.

Supplementary Figure 2: Maximum Likelihood phylogenetic tree of the bacterial 16S cDNA sequences in the Guaymas Basin cold seep sediments, performed using RAxML 7.2.8 and GTRCAT model approximation with 1000 replicates. Only bootstrap values above $70 \%$ are shown. Sequences amplified from sections 0 to $4 \mathrm{cmbsf}$ are labeled "Top", sequences from 4 to $6 \mathrm{cmbsf}$ are "Middle" and sequences from $8 \mathrm{cmbsf}$ to the end of the core are tagged "Bottom". Only one representative sequence is shown. Number in brackets indicate the number of similar clones (above $97 \%$ similarity). White MAT12, WM12; White MAT14, WM14; EWM14, Edge of White MAT14.

Supplementary Table 1: PCR primers used for real-time PCR of 16S rDNA genes.

Supplementary Table 2: Oligonucleotide probes used for fluorescence in situ hybridization. 
A White MAT12

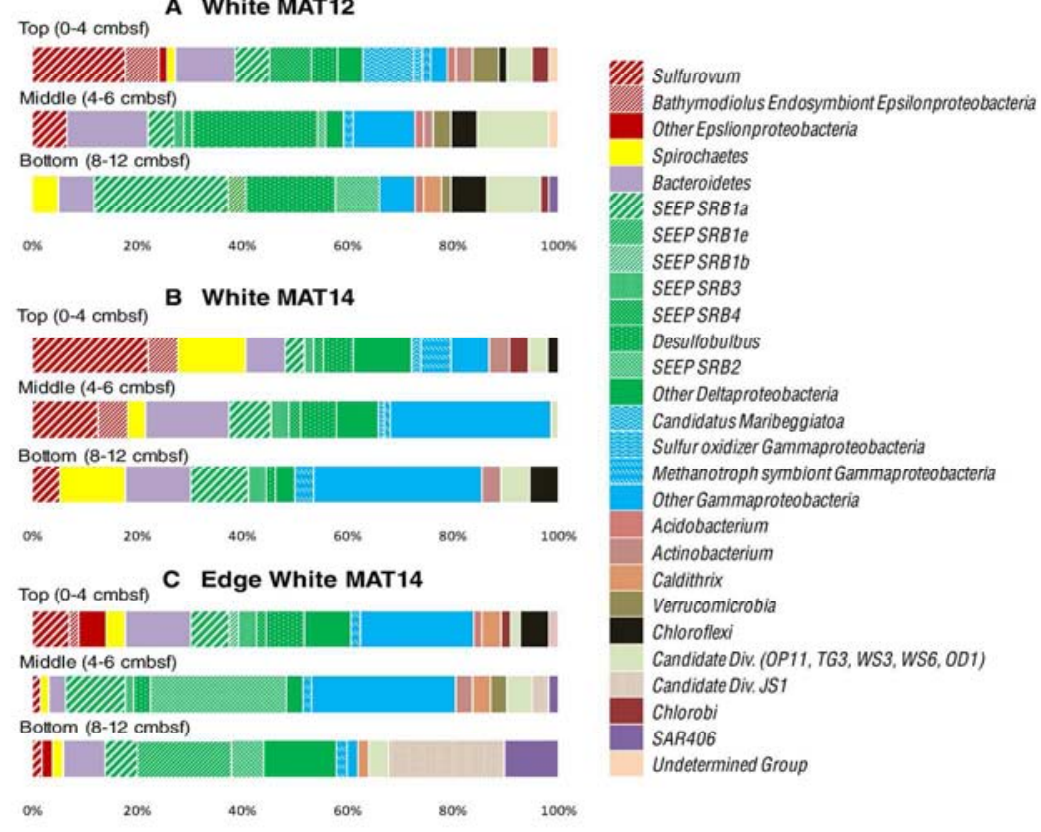

Phylogenetic affiliations of bacterial $16 \mathrm{~S}$ cDNA sequences for cold seep sediments of the Sonora Margin from Top (0 to $4 \mathrm{cmbsf}$ ), Middle ( 4 to $6 \mathrm{cmbsf}$ ) and Bottom ( 8 to $12 \mathrm{cmbsf}$ ). Shades of red, green, and blue denote putative Proteobacteria (Epsilon-, Delta- and Gamma- respectively). A,B and C correspond to the three selected habitats : white MAT12, White MAT14 and Edge of White MAT14.

$648 \times 458 \mathrm{~mm}$ (72 x 72 DPI) 


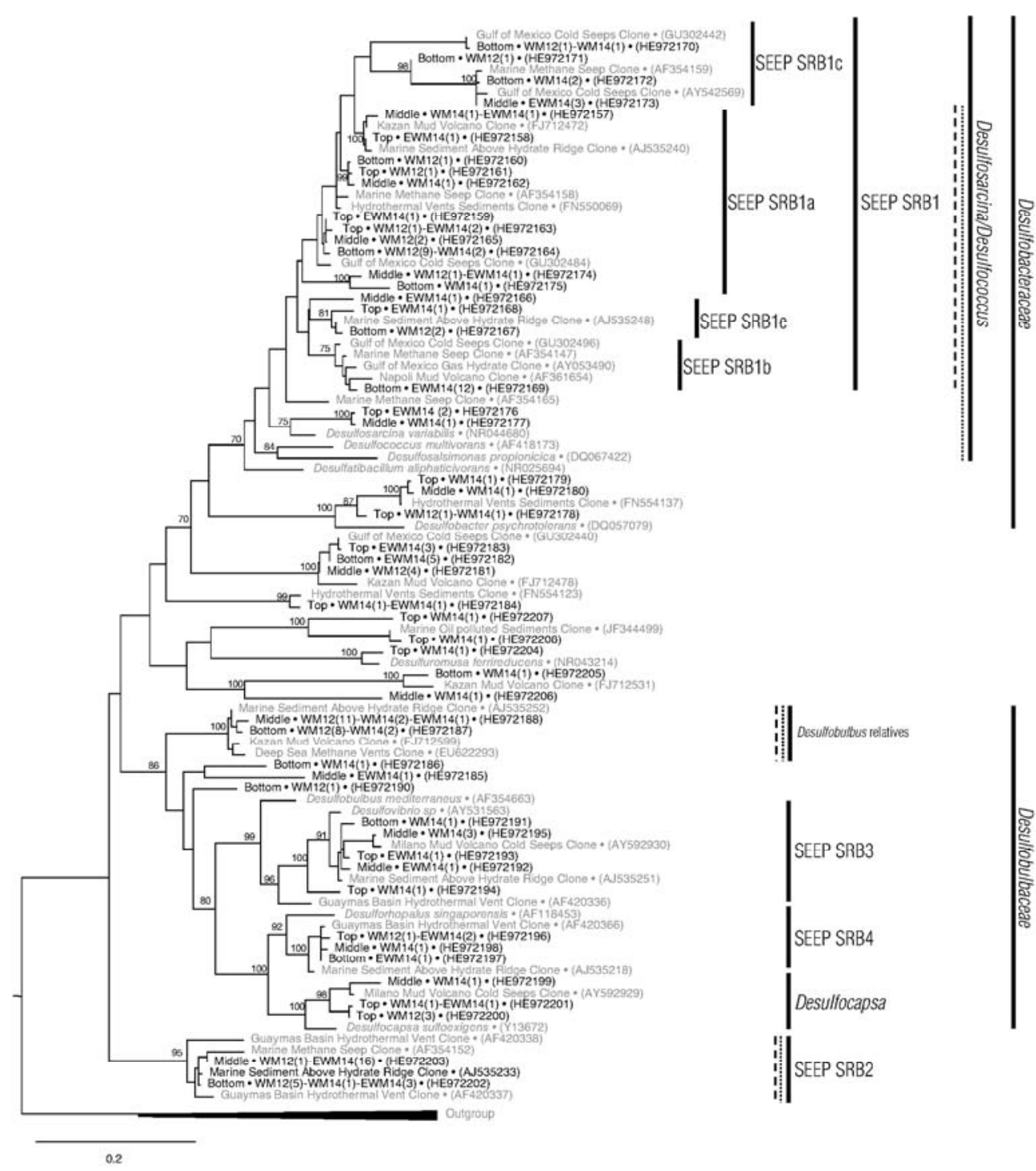

Maximum Likelihood phylogenetic tree of the bacterial Deltaproteobacteria 16S cDNA sequences in sediments of the Sonora Margin cold seeps performed using RAXML 7.2.8 and GTRCAT model approximation with 1000 replicates. Only bootstrap values up to $70 \%$ are shown. The scale bar indicates five substitutions per 100 nucleotides. Sequences amplified from sections 0 to $4 \mathrm{cmbsf}$ are labeled "Top", sequences from 4 to

$6 \mathrm{cmbsf}$ are "Middle" and sequences from $8 \mathrm{cmbsf}$ to end are tagged "Bottom". Only one representative sequence ( $>97 \%$ identical) is shown. Number in brackets shown the number of clones analyzed from RNA clone libraries. Dotted lines and dashes indicate sequences matching with corresponding Q-PCR primers and FISH probes, respectively. White MAT12, WM12; White MAT14, WM14; EWM14, Edge of White MAT14. $188 \times 208 \mathrm{~mm}(300 \times 300 \mathrm{DPI})$ 


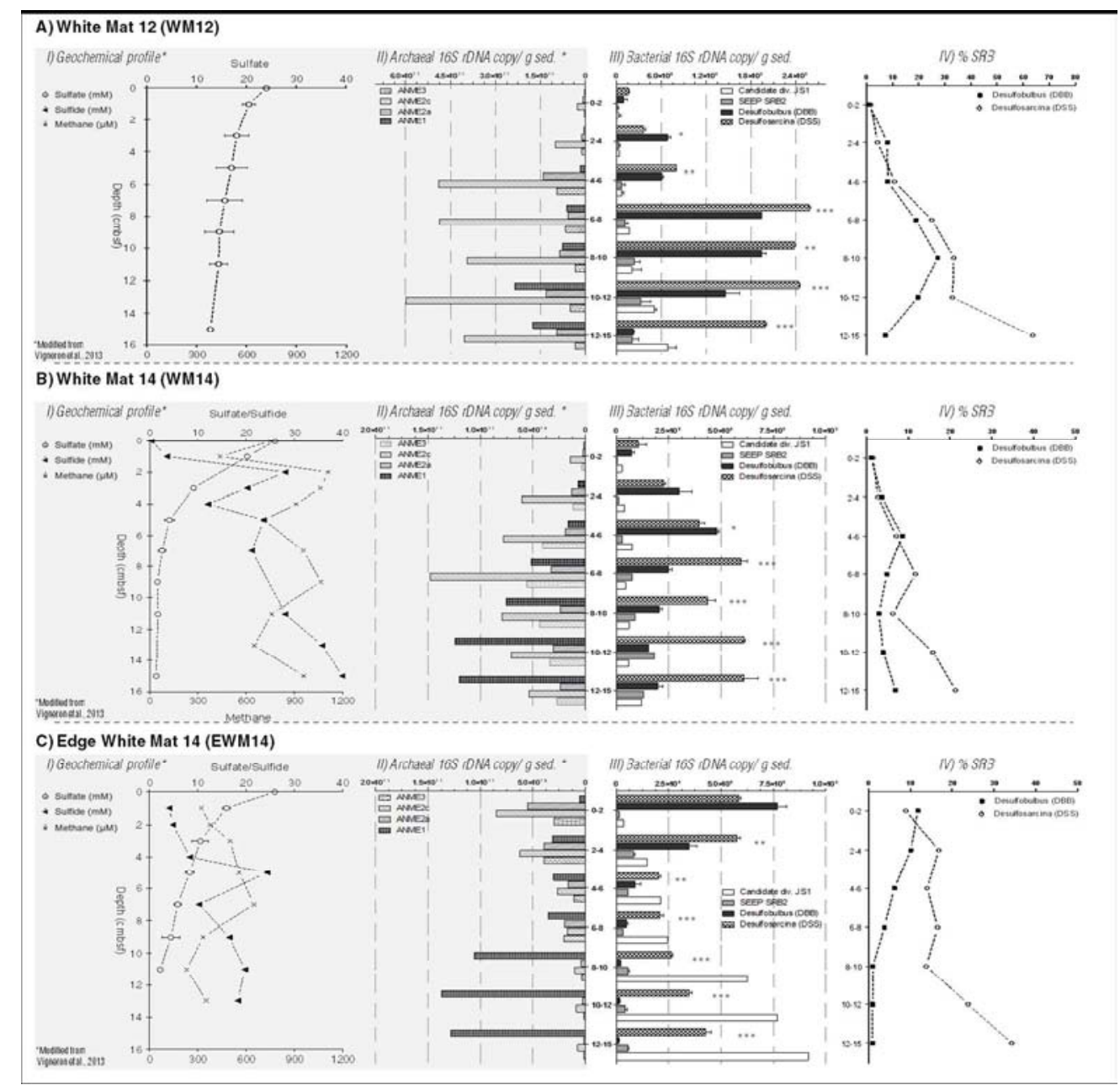

I Geochemical description of the three selected habitats A) White MAT12 (WM12), B) White MAT14 (WM14) and C) Edge White MAT14 (EWM14). Dissolved methane (cross), sulfate (open square) and sulfide (black square) concentrations in porewaters. II DNA copy numbers of the $16 \mathrm{~S}$ rDNA gene per gram of sediment for ANME groups previously observed on the same samples in the Sonora Margin sediments (Vigneron et al. 2013). III DNA copy numbers of the 16 S rDNA gene per gram of sediment for bacterial groups Desulfosarcina/Desulfoccocus, Desulfobulbus, SEEP SRB2 and candidate division JS1 in function of depth (0 to $15 \mathrm{cmbsf}$ ) in cold seep sediments of the Sonora Margin. Differences between DSS and DBB abundances were tested with t-test and labeled with $* * * \mathrm{p}<0.0001, * * \mathrm{p}<0.001$ and $* \mathrm{P}<0.01$. IV Proportion of sulfate reducing bacteria to total bacterial community previously estimated by Q-PCR $260 \times 255 \mathrm{~mm}(150 \times 150 \mathrm{DPI})$ 


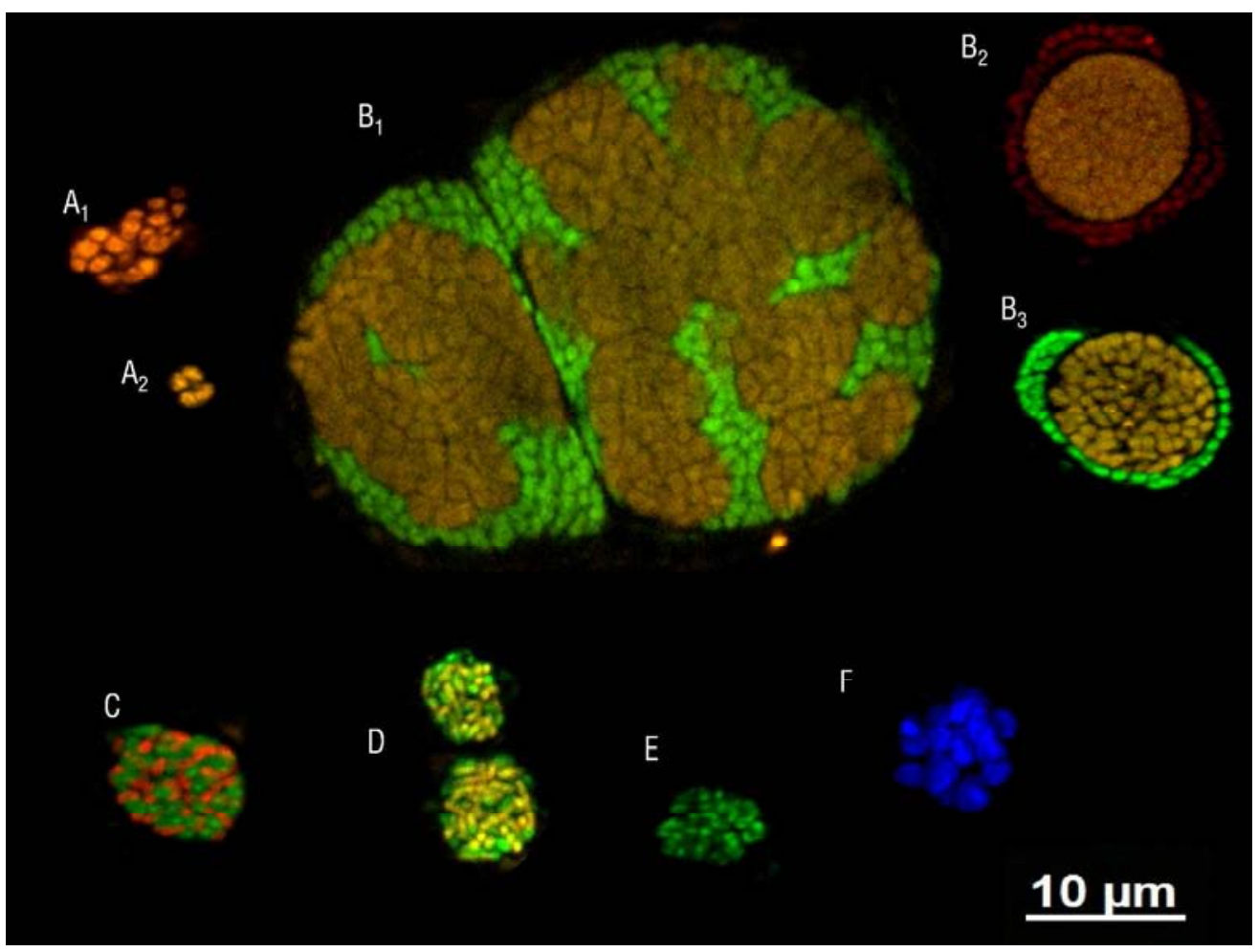

Individual cells and cell aggregates of ANMEs and bacterial partners visualized with fluorescent-labeled oligonucleotide probes. Each presented aggregate was taken from different pictures. A1 and A2) Monophyletic aggregate and single tetrad of SEEP SRB2 labeled with SEEP2-658 (Orange). B) Aggregates of ANME-2c (ANME2c-622 Yellow) and DSS cells (B1 and B3) or DBB cells (B2). C) Mixed aggregate of ANME2a (ANME2a-647/DSS (DSS-658 green). D) Tight aggregates of ANME-1 (ANME-1-350 -Yellow) and DSS (DSS-658 Green). E) Homogeneous aggregate of DSS cells labeled with DSS-658 probe (Green). F) Monospecific clusters of Gammaproteobacteria cells labeled with GAM42a probe (Blue). Scale is $10 \mu \mathrm{m}$. Pictures A B and F were from WM14 middle sediment layer, picture C from WM12 middle sediment layer, picture $D$ from the bottom sediment layer of WM12 and picture E from the deepest sediment layer of EWM14.

$253 \times 189 \mathrm{~mm}(300 \times 300 \mathrm{DPI})$ 


\section{Page 29 of 33}

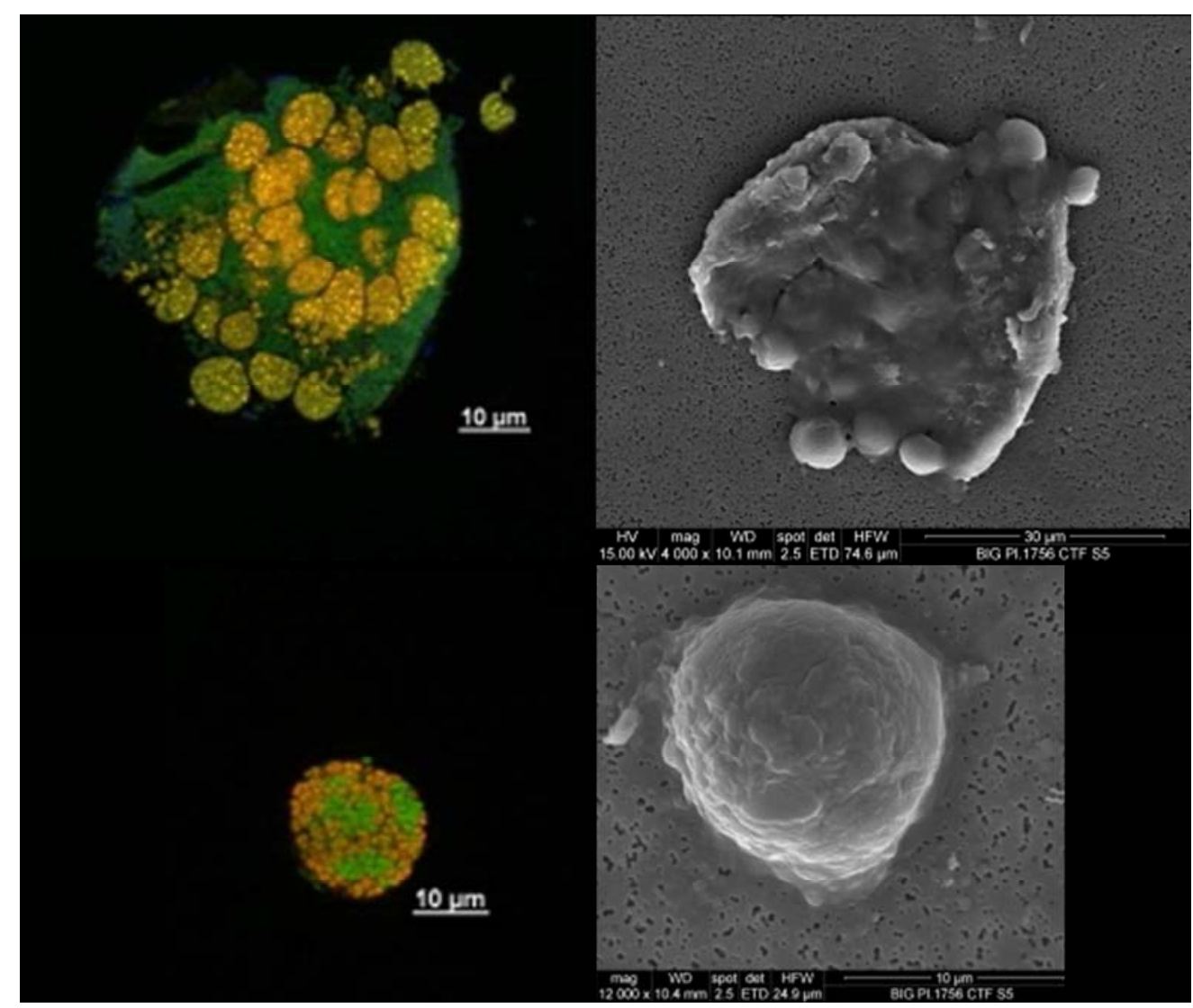

FISH (A1 and B1) and SEM (A2 and B2) observations of ANME-2c/Bacteria aggregates on WM12 bottom sediment layers.

$284 \times 240 \mathrm{~mm}(150 \times 150 \mathrm{DPI})$ 


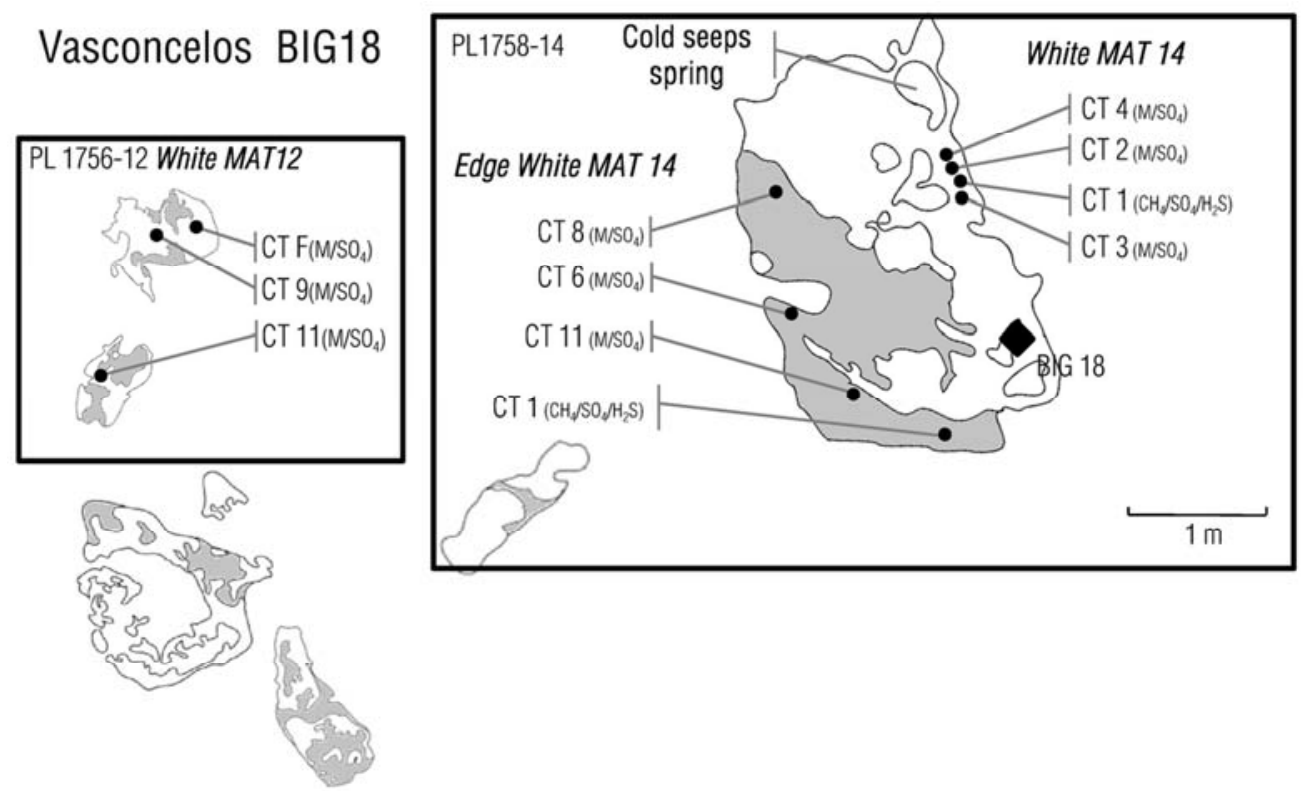

Schematic view of sampling sites around markers BIG18 (N 27035.5781; W 111 ${ }^{\circ} 28.9848$ ) with Nautile dives areas $(P L)$, relative position of push cores $(C T$, Diameter $5 \mathrm{~cm}$, length $30 \mathrm{~cm}$ ) and their geochemical measurements ( $\mathrm{CH} 4$ for methane concentrations, SO4 for sulfate and $\mathrm{H} 2 \mathrm{~S}$ for sulfide) and microbiological analysis (M). Scale is 1 meter. Modified from Vigneron et al., 2013. $102 \times 62 \mathrm{~mm}(300 \times 300 \mathrm{DPI})$ 


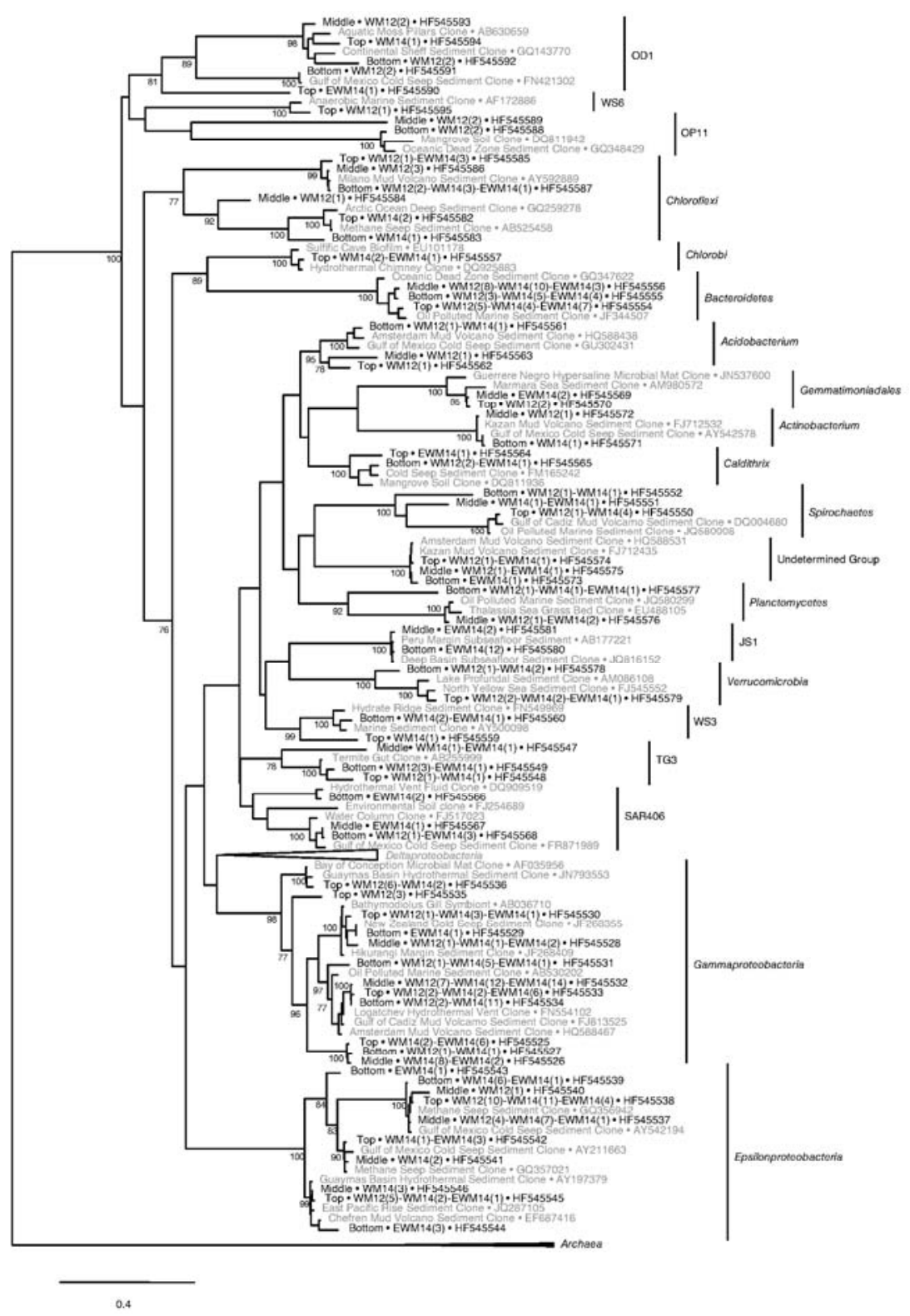

Maximum Likelihood phylogenetic tree of the bacterial 16S cDNA sequences in the Guaymas Basin cold seep sediments, performed using RAXML 7.2.8 and GTRCAT model approximation with 1000 replicates. Only bootstrap values above $70 \%$ are shown. The scale bar indicates five substitutions per 100 nucleotides. Sequences amplified from sections 0 to $4 \mathrm{cmbsf}$ are labeled "Top", sequences from 4 to $6 \mathrm{cmbsf}$ are "Middle" and sequences from $8 \mathrm{cmbsf}$ to the end of the core are tagged "Bottom". Only one representative sequence is shown. Number in brackets indicate the number of similar clones (above $97 \%$ similarity). White MAT12, WM12; White MAT14, WM14; EWM14, Edge of White MAT14. $176 \times 252 \mathrm{~mm}(300 \times 300 \mathrm{DPI})$ 
Table 1

\begin{tabular}{|c|c|c|c|c|c|c|c|}
\hline Name & Target group & Sequence $\left(5^{\prime}-3^{\prime}\right)$ & $\begin{array}{l}\text { Amplicon } \\
\text { size (bp) }\end{array}$ & $\begin{array}{l}\text { Annealing } \\
\text { Temp. } \\
\left({ }^{\circ} \mathrm{C}\right)\end{array}$ & $\begin{array}{l}\text { Primer } \\
\text { conc. } \\
\text { (mM) }\end{array}$ & $\begin{array}{l}\text { Maching } \\
\text { Efficiency } \\
(\%)^{a} \\
\end{array}$ & $\begin{array}{l}\text { Potential } \\
\text { false-positive }\end{array}$ \\
\hline $\begin{array}{l}\text { DSS-649F } \\
\text { DSS-808R }\end{array}$ & $\begin{array}{l}\text { Desulfosarcinales/ } \\
\text { Desulfococcales } \\
\text { group }\end{array}$ & $\begin{array}{l}\text { ACT-TGA-GTA-TGG-GAG-AGG-GAA-G } \\
\text { ACC-TAG-TGT-TCA-CCG-TTT-ACT-GC }\end{array}$ & 180 & 60 & 1 & $\begin{array}{l}72.6 \\
51.8\end{array}$ & None \\
\hline $\begin{array}{l}\text { DBB-649F } \\
\text { DBB-808R }\end{array}$ & Desulfobulbus group & $\begin{array}{l}\text { GCT-TGA-GTA-TGG-GAG-GGG-A } \\
\text { CAC-CTA-GTT-CTC-ATC-GTT-TAC-AGC }\end{array}$ & 180 & 60 & 1 & $\begin{array}{l}86.6 \\
86.6\end{array}$ & None \\
\hline $\begin{array}{l}\text { SRB2-649F } \\
\text { SRB2-808R }\end{array}$ & SEEP SRB-2 group & $\begin{array}{l}\text { ACT-TGA-GTA-CCG-GAG-AGG-GA } \\
\text { CCT-AGT-GCC-CAT-CGT-TTA-GG }\end{array}$ & 180 & 60 & 1 & $\begin{array}{l}83.8 \\
88.3\end{array}$ & $\begin{array}{l}\text { Myxococcales } \\
\text { and DTB120 }\end{array}$ \\
\hline
\end{tabular}

analyzed by the ARB program 
Table 2

\begin{tabular}{|c|c|c|c|c|}
\hline Name & Target group & Sequence $\left(5^{\prime}-3^{\prime}\right)$ & $\begin{array}{l}\text { Formamide } \\
\text { (\%) }\end{array}$ & Ref. \\
\hline Eub338 & Bacteria & GCT-GCC-TCC-CGT-AGG-AGT & 35 & $\begin{array}{l}\text { (Amann et al } \\
1990)\end{array}$ \\
\hline Arch915 & Archaea & GTG-CTC-CCC-CGC-CAA-TTC-CT & 35 & $\begin{array}{l}\text { (Amann et al } \\
\text { 1990) }\end{array}$ \\
\hline ANME1-350 & ANME-1 & AGT-TTT-CGC-GCC-TGA-TGC & 40 & $\begin{array}{l}\text { (Boetius et al } \\
2000 \text { ) }\end{array}$ \\
\hline ANME2c-622 & ANME-2c & CCC-TTG-GCA-GTC-TGA-TTG & 50 & (Knittel et al 2009) \\
\hline ANME2a-647 & ANME-2a & TCT-TCC-GGT-CCC-AAG-CCT & 50 & (Knittel et al 2009) \\
\hline DSS-658 & $\begin{array}{l}\text { Desulfosarcinales/ } \\
\text { Desulfococcales }\end{array}$ & TCC-АСТ-ТСС-СТС-ТСС-САТ & 50 & (Manz et al 1997) \\
\hline DBB-660 & Desulfobulbus & GAA-TTC-CAC-TTT-CCC-CTC-TG & 60 & $\begin{array}{l}\text { (Devereuz et al } \\
\text { 1992) }\end{array}$ \\
\hline SEEP-SRB4 & SEEP SRB-4 & CCC-CCT-CCA-GTA-CTC-AAG & 20 & $\begin{array}{l}\text { (Schreiber et al } \\
\text { 2010) }\end{array}$ \\
\hline SEEP2-658 & SEEP SRB-2 & TCC-ACT-TCC-CTC-TCC-GGT & 45 & $\begin{array}{l}\text { (Kleindienst et al } \\
\text { 2012) }\end{array}$ \\
\hline GAM42a & Gammaproteoacteria & GCC-TTC-CCA-CAT-CGT-TT & 35 & (Manz et al 1992) \\
\hline
\end{tabular}

